\title{
Case report - septic arthritis of the knee in a newborn
}

Marta Rosário1, Ana Reis e Melo1, Vicente Rey Y Formoso', Ana Rita Batista ${ }^{2}$, Cristina Castro ${ }^{1,3}$, Gilberto Costa ${ }^{4}$, Hercília Guimarães $^{5}$, Margarida Tavares ${ }^{1.3}$ 1 Pediatrics Service, Hospital Pediátrico Integrado, Centro Hospitalar de São João, Porto; 2 Pediatrics Service, Centro Hospitalar de Trás-os-montes, Vila Real; 3 Pediatric Infectious Disease Unit, Hospital Pediátrico Integrado, Centro Hospitalar de São João, Porto; 4 Child Orthopedics Unit, Centro Hospitalar de São João, Porto; 5 Neonatology Service, Hospital Pediátrico Integrado, Centro Hospitalar de São João, Porto;

\section{Background}

Septic arthritis represents an intra-articular infection caused by pyogenic bacteria, being rare in neonates. Delay in diagnosis or treatment may result in irreversible damage to the joint.

Case report

-, 24 days

- 40 weeks, eutocic birth

- Negative maternal serologies (3rd trim)

- Negative b gr. Streptococcus (cultured rectal exudate after 35 weeks of gestation)

\section{Physical exam}

- Left knee: edema, increased temperature and flushing

- Preferably in flexion

- Impaired range of movement

\section{Emergency department}

- Decreased mobility of the left lower limb

- Intense crying

- No fever, vomiting or diuresis changes

\section{Blood workout:}

- 12,900/ul leukocytes (4360/ul neutrophils)

- C-reactive protein $44 \mathrm{mg} / \mathrm{dl}$

- Procalcitonin 0.2ng/ml
- Radiography and MRI: Small joint effusion with no signs of osteomyelitis
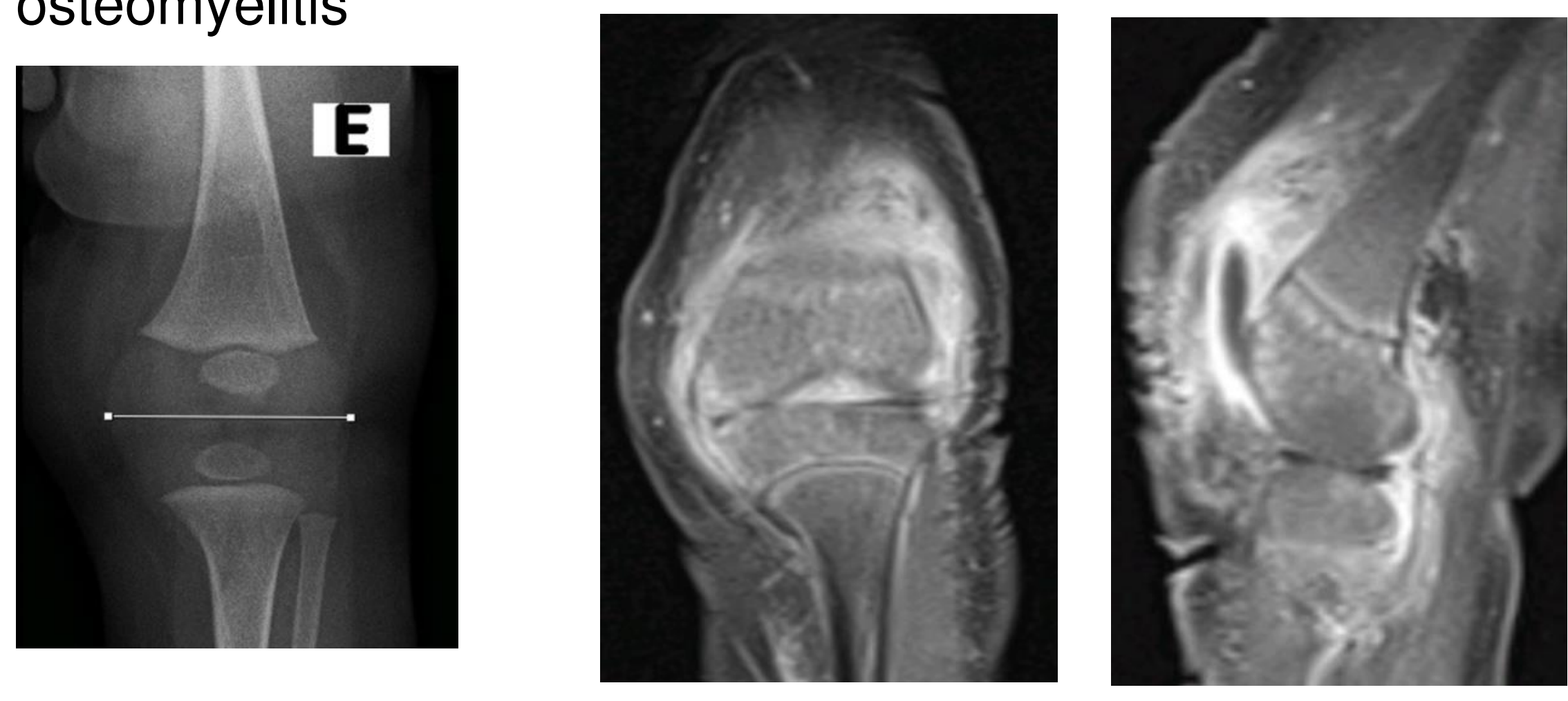

Septic arthritis ?

\section{Septic ar}

Arthrotomy with drainage and lavage

Flucloxacilin $(200 \mathrm{mg} / \mathrm{kg} /$ day)

Cefotaxime $(200 \mathrm{mg} / \mathrm{kg} /$ day $)$

Ampicillin $(200 \mathrm{mg} / \mathrm{kg} / \mathrm{day})$ - 4 weeks

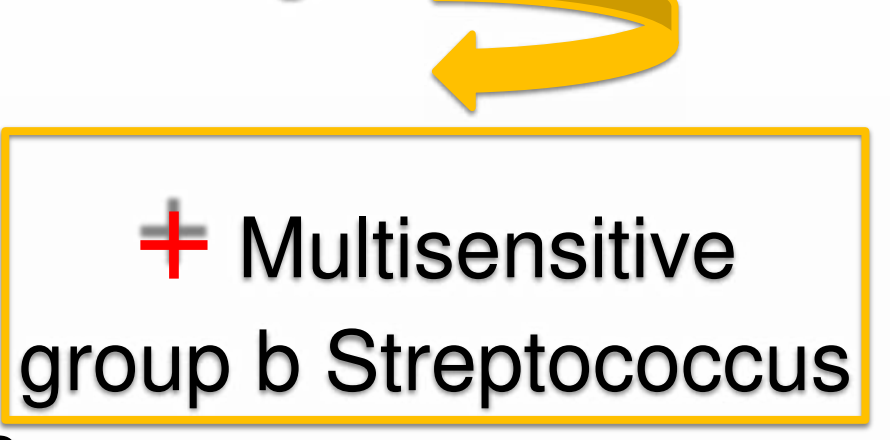

Positive clinical and analytical evolution. C-reactive protein $11 \mathrm{mg} / \mathrm{dl}$

\section{Discussion/Conclusion}

Septic arthritis in the neonate is a serious condition which could result in permanent dysfunction or deformity of the limbs. Staphylococcus aureus is the most frequent agent but others like group b Streptococcus can cause septic arthritis, particularly at this age. This case reminds that group B streptococcus can colonize birth canal and be negative when searched during pregnancy, so although rare, has to be considered in newborns. 